\title{
Comparative dispersal of larvae from demersal versus pelagic spawning fishes
}

\author{
Michael J. H. Hickford ${ }^{1,2, *}$, David R. Schiel ${ }^{1}$ \\ ${ }^{1}$ Marine Ecology Research Group, Department of Zoology, University of Canterbury, Private Bag 4800, Christchurch, New Zealand \\ ${ }^{2}$ Present address: Marine Science Institute, University of California, Santa Barbara, California 93106-6150, USA
}

\begin{abstract}
We conducted ichthyoplankton surveys on the east coast of the South Island, New Zealand, to address 2 questions: (1) Are certain types of reef fish larvae more likely to be dispersed on an exposed temperate coast? (2) Is larval dispersal more strongly associated with taxa that have pelagic eggs? Analyses were based on 492 plankton net samples collected perpendicular to the shore $(0.05,2,4$ and $6 \mathrm{~km}$ offshore) and parallel to the shore (0.05, 0.1, 0.3 and $1 \mathrm{~km}$ alongshore) from a rocky reef environment. We caught 60 taxa belonging to 32 families, but 11 taxa accounted for $97 \%$ of all larvae collected. Only these common taxa were considered further. Larvae from the 3 taxa with pelagic eggs (Sprattus spp., Aldrichetta forsteri and Rhombosolea plebeia) showed varying degrees of dispersal that ranged from increased abundance close to shore to no clear pattern with distance from shore or alongshore from a rocky reef environment. Larvae from the 1 viviparous taxon (unidentified scorpaenids) were more abundant close to shore. Larvae from the 2 taxa with freshwater demersal eggs (unidentified retropinnids and galaxiids) had disparate patterns of offshore and alongshore dispersal. Retropinnids occurred almost exclusively at the nearshore stations, but galaxiids were more abundant further from shore and were only found nearshore adjacent to a river mouth. Larvae from the 5 taxa that hatched from marine demersal eggs (unidentified tripterygiids, Forsterygion spp., Gilloblennius tripennis, Grahamina capito and Ruanoho decemdigitatus) were all more common further from shore. For the taxa in this study, we reject the hypothesis that reef fish larvae that hatch from non-pelagic eggs are retained mostly or exclusively near reefs on an exposed coast. Broad-scale dispersal of fish larvae may provide benefits in terms of predator avoidance, recolonisation of habitats and risk-spreading, but it carries with it the increased risk of unfavourable advection that may delay or even prevent recruitment.
\end{abstract}

KEY WORDS: Fish larvae · Dispersal · Rocky reefs $\cdot$ Reef fish $\cdot$ New Zealand Resale or republication not permitted without written consent of the publisher

\section{INTRODUCTION}

Reef fish larvae may disperse widely during their planktonic phase. Planktonic dispersal is considered to offer an adaptive advantage, but there is disagreement as to the nature of this advantage. Johannes (1978) suggested that planktonic dispersal enables larvae to avoid planktivorous reef fishes. Barlow (1981) asserted that planktonic dispersal gives reef fish species the ability to migrate in their early life stages between the patchy environments that adults inhabit but cannot bridge. Doherty et al. (1985) argued that substantial planktonic dispersal is adaptive when the propagules experience uneven and unpredictable survival in the pelagic environment. In this situation, substantial dispersal is a means of risk-spreading in a heterogeneous space, even though dispersal may incur additional mortality (Kuno 1981, Metz et al. 1983). Although there is limited evidence to support these hypotheses, the paradigm is widespread that reef fish larvae should disperse so that they develop further from shore rather than near reefs.

Despite some benefits from the dispersal of reef fish larvae, there are also disadvantages. For instance, it is necessary for larvae to return to a habitat suitable for settlement at the completion of their planktonic phase. 
The scale of most dispersal makes active migration unlikely, but there are a variety of oceanographic processes that can transport reef fish larvae back to the nearshore environment (see review by Kingsford 1990). However, such processes are likely to be variable both in their presence and in their effectiveness. If larvae that are competent to settle are not transported back to shore, or if they are transported to an unsuitable habitat, then they are effectively lost.

These potential losses have led several authors to investigate the alternative strategy of reef fish larvae being retained near reefs during their planktonic phase. Brogan (1994) suggested that such a distribution would have consequences on the mortality rate of larvae both before and after they become competent to settle. The presence of predators and increased competition for food may increase the pre-competent larval mortality rate in the reef environment. However, once competent to settle, larvae that are near reefs are able to settle quickly, while more distant larvae may have to delay settlement until a suitable habitat is encountered, thereby risking further mortality.

Many reef fish species are pelagic spawners, and wind- and tide-induced currents will passively disperse their eggs, unless favourable hydrographic conditions prevail (Black et al. 1991, Black 1993). Pelagic eggs are generally smaller than demersal eggs, and usually produce smaller larvae (3 to $5 \mathrm{~mm}$ ) (Thresher 1984) with less-developed sensory systems and swimming abilities (Blaxter 1986, Miller et al. 1988). The newly hatched larvae may undergo further passive dispersal before becoming functionally competent. Nonpelagic spawners (viviparous and demersal spawners) incubate their eggs on the reef and, in many cases, delay hatching or birth until the resulting larvae have reached a comparatively large size (5 to $10 \mathrm{~mm}$ ) (Thresher 1984) with functional fins, eyes and guts (Barlow 1981, Hunter 1981, Thresher 1984). This combination of better swimming ability and more developed sensory systems may make retention more likely for non-pelagic spawners, particularly those species that hatch as large, well-developed larvae.

Several authors have found evidence of retention of reef fish larvae in temperate waters. On the Canadian west coast, larvae from demersal eggs were dominant inshore and had a restricted alongshore distribution, favouring a rocky shoreline over sand (Marliave 1986). In contrast, larvae originating from pelagic eggs were more uniformly distributed both alongshore and offshore. Off SW Nova Scotia, larvae from demersal eggs dominated the inshore shallow-water environment, while densities of larvae originating from pelagic eggs were not correlated with bathymetry (Suthers \& Frank 1991). The authors concluded that larvae from demersal eggs were more spatially persistent through the release of well-developed larvae from non-drifting eggs.

In the Gulf of California, Mexico, several families, including sandy bottom and reef fish, utilised the nearreef habitat throughout their development (Brogan 1994). These families all spawned non-pelagic eggs and had well-developed hatchlings, but the larvae of other families, with similar spawning patterns, were not retained. Off central New South Wales, Australia, larvae from taxa with demersal eggs or that were viviparous were more abundant close to shore (Gray 1993). However, some larvae that originated from pelagic eggs also predominated nearshore. In NE New Zealand, the larvae from taxa that spawn demersal eggs were more abundant near reefs (Kingsford \& Choat 1989). All larval size classes were present near reefs, and these taxa were absent or rare further from shore. However, the authors noted that the pelagicdemersal retention distinction was not consistent, as the distribution of several demersal spawning families was not influenced by the proximity of reefs.

Although several authors have identified the nearshore retention of reef fish larvae in temperate regions, most of these studies have been done on protected shorelines. The northward-moving Southland Current sweeps most of the east coast of the South Island of New Zealand (Heath 1972a). The mean currents in the Kaikoura region are thought to flow from the south (Chiswell \& Schiel 2001), but there is some variability in flow, and on occasion Kaikoura is bathed by subtropical water from the north (Shaw \& Vennell 2000). However, coastal surface waters south of the Kaikoura Peninsula are commonly exposed to a current moving northward at approximately $7 \mathrm{~cm} \mathrm{~s}^{-1}$ (Heath 1972c). Of interest is whether retention can still occur on a coastline exposed to a moderate current as well as large oceanic swells and frequent storm events. In this paper, we describe a study of larval fish distribution offshore and alongshore from a rocky reef environment on an exposed temperate coast. The 2 main questions addressed were: (1) Are certain types of reef fish larvae more likely to be dispersed on an exposed temperate coast? (2) Is larval dispersal more strongly associated with taxa that have pelagic eggs?

\section{MATERIALS AND METHODS}

Perpendicular-to-shore sampling. To test for the effects of distance from shore on ichthyoplankton assemblages, we conducted fortnightly surveys between October 1995 and May 1997 at 4 stations (Table 1) along a transect that extended $6 \mathrm{~km}$ perpendicular to the south shore of the Kaikoura Peninsula (Fig. 1). Sampling was completed during daylight hours in the 
Table 1. Location, distance from shore, water depth and distance to rocky reef environment of perpendicular- and parallel-to-shore stations

\begin{tabular}{|c|c|c|c|c|}
\hline Station & Location & $\begin{array}{l}\text { Distance from shore } \\
\qquad(\mathrm{km})\end{array}$ & $\begin{array}{l}\text { Depth } \\
\text { (m) }\end{array}$ & $\begin{array}{l}\text { Distance from reef } \\
(\mathrm{km})\end{array}$ \\
\hline \multicolumn{5}{|c|}{ Perpendicular } \\
\hline $0.05 \mathrm{~km}$ & $42^{\circ} 29.750^{\prime} \mathrm{S}, 173^{\circ} 40.886^{\prime} \mathrm{E}$ & 0.05 & 12 & 0.05 \\
\hline $2 \mathrm{~km}$ & $42^{\circ} 26.837^{\prime} \mathrm{S}, 173^{\circ} 40.819^{\prime} \mathrm{E}$ & 2 & 56 & 2 \\
\hline $4 \mathrm{~km}$ & $42^{\circ} 27.921^{\prime} \mathrm{S}, 173^{\circ} 40.883^{\prime} \mathrm{E}$ & 4 & 83 & 4 \\
\hline $6 \mathrm{~km}$ & $42^{\circ} 29.001^{\prime} \mathrm{S}, 173^{\circ} 40.809^{\prime} \mathrm{E}$ & 6 & 850 & 6 \\
\hline \multicolumn{5}{|l|}{ Parallel } \\
\hline $0.05 \mathrm{~km}$ & $42^{\circ} 29.750^{\prime} \mathrm{S}, 173^{\circ} 40.886^{\prime} \mathrm{E}$ & 0.05 & 12 & 0.05 \\
\hline $0.1 \mathrm{~km}$ & $42^{\circ} 25.022^{\prime} \mathrm{S}, 173^{\circ} 40.424^{\prime} \mathrm{E}$ & 0.05 & 8 & 0.1 \\
\hline $0.3 \mathrm{~km}$ & $42^{\circ} 24.978^{\prime} \mathrm{S}, 173^{\circ} 39.543^{\prime} \mathrm{E}$ & 0.05 & 9 & 0.3 \\
\hline $1 \mathrm{~km}$ & $42^{\circ} 25.144^{\prime} \mathrm{S}, 173^{\circ} 38.405^{\prime} \mathrm{E}$ & 0.05 & 9 & 1 \\
\hline
\end{tabular}

early morning (06:00 to 08:00 h). Neustonic ichthyoplankton were sampled using a plankton net with a $707 \times 707 \mathrm{~mm}$ mouth $\left(0.5 \mathrm{~m}^{2}\right)$ and $280 \mu \mathrm{m}$ mesh. The net was a box-pyramid design with a filtration efficiency of 1:11. A General Oceanics flowmeter (Model 2030R) was fitted within the mouth of the net (positioned at 0.33 of the net width) to determine the volume of water filtered per tow. The net was towed beside a $6 \mathrm{~m}$ boat to avoid disturbance caused by the wake. The top of the net's frame was suspended from a gantry so that it sampled with the uppermost edge of the net at a fixed height of $10 \mathrm{~cm}$ above the sea surface. A $25 \mathrm{~kg}$ Scripps depressor was suspended from the lower edge of the frame to keep the mouth of the net vertical. The net was towed from a 4 -point bridle that joined above the waterline to avoid disturbance by the

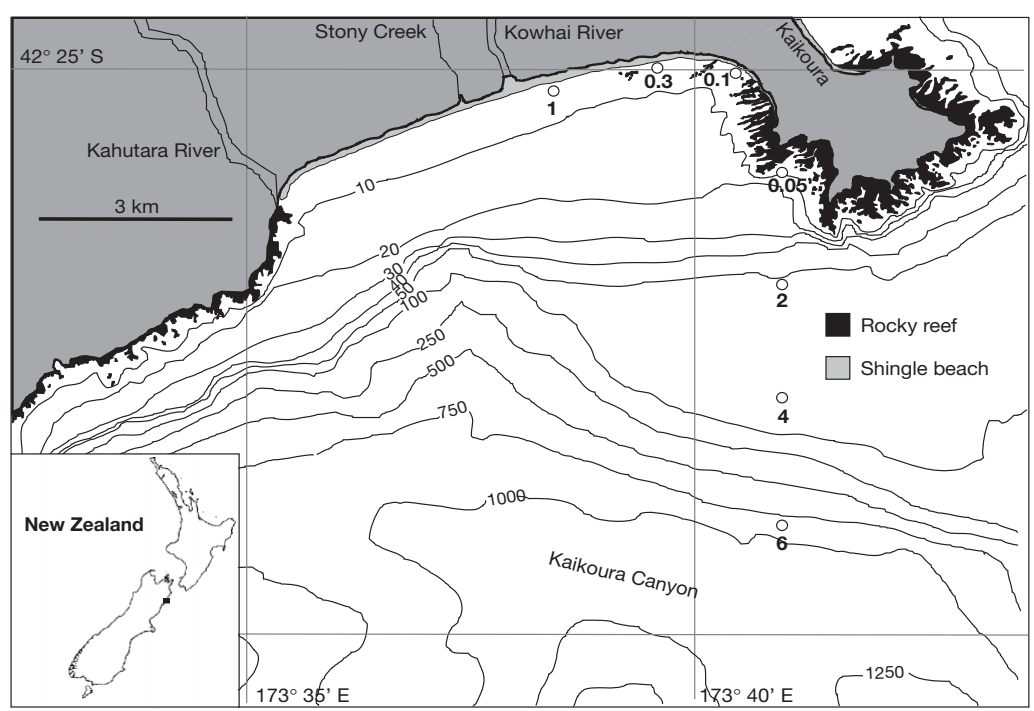

Fig. 1. Map of Kaikoura Peninsula on NE coast of the South Island of New Zealand. The 4 perpendicular-to-shore stations $(0.05,2,4$ and $6 \mathrm{~km})$ and the 4 parallel-to-shore stations $(0.05,0.1,0.3$ and $1 \mathrm{~km})$ are shown. Bathymetry is in metres wire strops. At each station, 3 tows of 15 min each were made at a speed of approximately $1.3 \mathrm{~m} \mathrm{~s}^{-1}$. The net filtered an average of $500 \mathrm{~m}^{3}$ of water per replicate.

Parallel-to-shore sampling. To test for the effects of alongshore distance from rocky reef on ichthyoplankton assemblages, we sampled at 4 stations parallel to the south coast of the Kaikoura Peninsula (Fig. 1): 3 stations were $50 \mathrm{~m}$ offshore from a fine shingle beach (5 to $10 \mathrm{~mm}$ particle diameter) but differed in their proximity to rocky reefs (Table 1 ). The fourth station $(0.05 \mathrm{~km})$ was $50 \mathrm{~m}$ offshore from a rocky coastline.

Ichthyoplankton surveys were done at the 4 stations during 2 periods (28 to 29 January 1997 and 18 to 19 February 1997) in late summer and during 2 periods (2 to 3 April 1997 and 16 to 17 April 1997). in midautumn. Logistical constraints required that 2 stations be sampled on each of 2 consecutive days. The 4 stations were sampled in random order. Sampling was completed during daylight hours in the early morning (06:00 to 08:00 h). Neustonic ichthyoplankton were sampled at each station using the same procedure and net as described above.

After each replicate was taken, the net was washed thoroughly with pumped seawater and the sample was fixed in buffered $10 \%$ formalin in seawater. All fish larvae were removed from the samples with the aid of a dissection microscope, identified to the lowest possible taxonomic level, counted and stored in buffered $2 \%$ formalin in freshwater. Counts were standardised to the number of fishes $500 \mathrm{~m}^{-3}$. Clupeid, retropinnid and galaxiid larvae could not be identified beyond the family or genus level because of the similarity of larvae 
from different species and the presence of adults from several species of each of these families in the study area. Small scorpaenids, labrids, tripterygiids, centrolophids and pleuronectids also could not be identified below the family or genus level. All fishes (except those that were badly damaged) were measured to the nearest $0.5 \mathrm{~mm}$ by placing them on a graduated slide. Notochord length was measured for preflexion and flexion larvae, and standard length was measured for postflexion larvae.

Analysis. During this study, 2 types of data were collected. The ichthyoplankton samples contained a wide range of taxa, allowing tests on the temporal and spatial distribution of individual taxa. Because all undamaged fish larvae were measured, the size of larvae could also be compared temporally and spatially.

We used 2-factor Model I ANOVAs, with time (up to 37 occasions) and distance from shore (4 stations) as factors, to compare the abundance of commonly occurring taxa at the perpendicular-to-shore stations. The number of occasions that were compared in each ANOVA varied between taxa because any occasion when no larvae (of the taxon of interest) were collected was excluded from the analysis. Prior to ANOVA, the data for each taxon were tested for homogeneity of variances using Cochran's test, and all data became homogeneous when $\log (x+1)$-transformed. Tukey's honest significant difference (HSD) tests were used for post-hoc comparisons of means.

We used 2 separate ANOVAs to compare the size of larvae from each commonly occurring taxon caught during the perpendicular and parallel-to-shore sampling. Tukey HSD tests for unequal numbers were used for post-hoc comparisons of means. Temporal variability could not be formally tested because larvae from even the most common taxa were not caught on all, or even most, occasions.

ANOVA was used to compare the size of unidentified tripterygiid and Forsterygion spp. larvae caught at the perpendicular and parallel-to-shore stations during the same period (27 January 1997 to 18 April 1997). Tukey HSD tests for unequal numbers were used for post-hoc comparisons of means.

\section{RESULTS}

The 444 samples from the perpendicular-to-shore stations collected 28638 larval and pelagic juvenile fishes from 31 families (Table 2). We identified 56 taxa, including 8 that contained $>1$ species (identifiable to the family or genus level) and 3 unidentified taxa. The 3 most abundant taxa (unidentified tripterygiid, Grahamina capito and unidentified scorpaenid) accounted for $64 \%$ of the total catch; 43 taxa each comprised
$<0.2 \%$ of the total number of larvae collected. Instead of occurring in very low numbers throughout the sampling period, most of the less numerous taxa occurred in only a few samples.

The 48 samples from the parallel-to-shore stations collected 2538 larval and pelagic juvenile fishes from 15 families (Table 2). We identified 22 taxa including 7 that contained $>1$ species (identifiable to the family or genus level). The 4 most abundant taxa (unidentified retropinnid, Aldrichetta forsteri, unidentified scorpaenid and Forsterygion spp.) accounted for $87 \%$ of the total catch; 13 taxa each comprised $<1 \%$ of the total number of larvae collected.

Of the 60 taxa collected in the perpendicular and parallel-to-shore samples, only 11 were relatively abundant and present in both sampling types. Further analysis involved only these 11 common taxa. There was considerable variation among these taxa with regard to the habitat occupied by their adults and their mode of spawning (Table 3). The adults of most of the common taxa occupied rocky reef habitats, but anadromous (retropinnids), amphidromous (galaxiids) and pelagic taxa were also common. Many larvae hatched from demersal eggs, but viviparous taxa and larvae from pelagic eggs were also common.

The abundance of the common taxa at the perpendicular-to-shore stations was highly variable through time (Table 4). However, all had a significant interaction between time and distance from shore that accounted for a large proportion of variance in the model. On most occasions, the nearshore and offshore abundances of all of the common taxa (except retropinnids and Grahamina capito) were not significantly different (Table 4). However, for most of the common taxa any differences in abundance, where they did occur, were consistent. For example, the number of G. capito larvae did not differ between the $0.05 \mathrm{~km}$ and other stations on 11 of the 23 occasions in which they were found. However, on each of the remaining 12 occasions, significantly fewer G. capito larvae were caught at $0.05 \mathrm{~km}$.

The 3 common taxa that produced pelagic eggs showed very different temporal and spatial distributions (Fig. 2). Sprattus spp. larvae were found throughout the year, but there were no clear patterns in their offshore or alongshore distributions (Fig. 2a). Small Sprattus spp. larvae $(6.5 \mathrm{~mm})$ appeared in early July (Fig. 3a), particularly at 0.05 and $2 \mathrm{~km}$, and the mean size of larvae at all stations increased until November/December. Smaller larvae appeared again in January, suggesting that a second spawning event had occurred. Small Sprattus spp. larvae were scarce further from shore (Fig. 3a, Table 5).

On the east coast of the South Island, sprat spawn between June and November (Colman 1979) with a peak (when the water is coldest) during August and 
Table 2. Composition of larval fishes caught in 444 perpendicular-to-shore and 48 parallel-to-shore samples. Total abundance (n), percentage of total catch (\%) and percentage occurrence (\% Occ.) are given for each taxon. -: taxon absent

\begin{tabular}{|c|c|c|c|c|c|c|c|}
\hline \multirow[t]{2}{*}{ Family } & \multirow[t]{2}{*}{ Taxon } & \multicolumn{3}{|c|}{ - Perpendicular } & \multicolumn{3}{|c|}{ Parallel - } \\
\hline & & $\mathrm{n}$ & $\%$ & $\%$ Occ. & $\mathrm{n}$ & $\%$ & $\%$ Occ. \\
\hline Clupeidae & Sprattus spp. & 213 & 0.77 & 17.1 & 6 & 0.2 & 6.3 \\
\hline Gonorynchidae & Gonorynchus gonorynchus & - & - & - & 1 & 0 & 2.1 \\
\hline Retropinnidae & Unidentified retropinnid & 1168 & 4.64 & 22.7 & 1751 & 69.0 & 93.8 \\
\hline Galaxiidae & Unidentified galaxiid & 400 & 1.60 & 25.9 & 59 & 2.3 & 6.3 \\
\hline Sternoptychidae & Maurolicus muelleri & 2 & 0.01 & 0.5 & - & - & - \\
\hline Photichthyidae & Vinciguerria attenuata & 1 & 0.003 & 0.2 & - & - & - \\
\hline \multirow{3}{*}{ Myctophidae } & Benthosema suborbitale & 1 & 0.003 & 0.2 & - & - & - \\
\hline & Gymnoscopelus piabilis & 187 & 0.62 & 10.1 & 1 & 0.04 & 2.1 \\
\hline & Symbolophorus boops & - & - & - & 6 & 0.2 & 8.3 \\
\hline \multirow[t]{3}{*}{ Moridae } & Unidentified morid & - & - & - & 3 & 0.1 & 2.1 \\
\hline & Auchenoceros punctatus & 28 & 0.10 & 6.1 & - & - & - \\
\hline & Pseudophycis bachus & 12 & 0.05 & 1.8 & - & - & - \\
\hline Gadidae & Gaidropsarus novaezelandiae & 26 & 0.09 & 3.8 & - & - & - \\
\hline Merlucciidae & Macruronus novaezelandiae & 5 & 0.02 & 1.1 & - & - & - \\
\hline Carapidae & Echiodon pegasus & 7 & 0.03 & 0.9 & - & - & - \\
\hline \multirow[t]{3}{*}{ Gobiesocidae } & Diplocrepis puniceus & - & - & - & 2 & 0.1 & 4.2 \\
\hline & Gastroscyphus hectoris & 1 & 0.003 & 0.2 & - & - & - \\
\hline & Trachelochismus melobesia & 8 & 0.03 & 0.9 & 10 & 0.4 & 14.6 \\
\hline Hemirhamphidae & Hyporhamphus ihi & 10 & 0.04 & 1.8 & - & - & - \\
\hline Scomberesocidae & Scomberesox saurus & 3 & 0.01 & 0.5 & - & - & - \\
\hline \multirow[t]{2}{*}{ Syngnathidae } & Hippocampus abdominalis & 28 & 0.10 & 5.2 & 3 & 0.1 & 6.3 \\
\hline & Leptonotus elevatus & 4 & 0.01 & 0.9 & - & - & - \\
\hline \multirow[t]{3}{*}{ Scorpaenidae } & Unidentified scorpaenid & 5379 & 20.04 & 33.1 & 158 & 6.2 & 66.7 \\
\hline & Helicolenus barathri & 23 & 0.10 & 2.3 & - & - & - \\
\hline & Scorpaena papillosus & 1 & 0.003 & 0.2 & - & - & - \\
\hline Congiopodidae & Congiopodus leucopaecilus & 2 & 0.01 & 0.5 & - & - & - \\
\hline Triglidae & Chelidonichthys kumu & 10 & 0.03 & 1.8 & - & - & - \\
\hline \multirow[t]{2}{*}{ Acanthoclinidae } & Acanthoclinus fuscus & 1 & 0.003 & 0.2 & - & - & - \\
\hline & Taumakoides rua & 3 & 0.01 & 0.5 & - & - & - \\
\hline Mugilidae & Aldrichetta forsteri & 493 & 1.81 & 15.3 & 167 & 6.6 & 39.6 \\
\hline \multirow[t]{2}{*}{ Labridae } & Notolabrus spp. & 14 & 0.05 & 1.4 & - & - & - \\
\hline & N. celidotus & 5 & 0.02 & 0.9 & 1 & 0.04 & 2.1 \\
\hline Bovichthyidae & Bovichtus variegatus & 139 & 0.47 & 9.5 & - & - & - \\
\hline Uranoscopidae & Genyagnus monopterygius & 1 & 0.003 & 0.2 & 1 & 0.04 & 2.1 \\
\hline \multirow[t]{7}{*}{ Tripterygiidae } & Unidentified tripterygiid & 6614 & 22.17 & 42.6 & 86 & 3.4 & 27.1 \\
\hline & Forsterygion spp. & 4206 & 14.69 & 42.6 & 133 & 5.2 & 39.6 \\
\hline & Gilloblennius tripennis & 2190 & 7.16 & 24.1 & 16 & 0.6 & 12.5 \\
\hline & Grahamina capito & 6436 & 21.80 & 35.6 & 46 & 1.8 & 25.0 \\
\hline & G. signata & 3 & 0.01 & 0.5 & - & - & - \\
\hline & Ruanoho decemdigitatus & 689 & 2.40 & 26.4 & 28 & 1.1 & 16.7 \\
\hline & Notoclinus fenestratus & 10 & 0.04 & 1.8 & - & - & - \\
\hline Eleotrididae & Grahamichthys radiata & 1 & 0.003 & 0.2 & - & - & - \\
\hline Gobiidae & Gobiopsis atrata & 2 & 0.01 & 0.5 & - & - & - \\
\hline Gempylidae & Thyrsites atun & 7 & 0.02 & 1.6 & - & - & - \\
\hline Istiophoridae & Hyperoglyphe antarctica & 1 & 0.003 & 0.2 & - & - & - \\
\hline \multirow[t]{3}{*}{ Centrolophidae } & Seriolella spp. & 14 & 0.06 & 2.5 & - & - & - \\
\hline & S. brama & 5 & 0.02 & 0.7 & - & - & - \\
\hline & S. caerulea & 3 & 0.01 & 0.7 & - & - & - \\
\hline Bothidae & Arnoglossus scapha & 10 & 0.03 & 1.8 & - & - & - \\
\hline & Lophonectes gallus & 2 & 0.01 & 0.5 & - & - & - \\
\hline Pleuronectidae & Pelotretis flavilatus & 1 & 0.004 & 0.2 & 1 & 0.04 & 2.1 \\
\hline & Peltorhamphus spp. & 1 & 0.003 & 0.2 & - & - & - \\
\hline & P. novaezelandiae & 3 & 0.01 & 0.5 & - & - & - \\
\hline & P. latus & 1 & 0.003 & 0.2 & - & - & - \\
\hline & Rhombosolea plebeia & 97 & 0.34 & 11.7 & 50 & 2.0 & 33.3 \\
\hline & R. retiaria & 1 & 0.003 & 0.2 & - & - & - \\
\hline Monacanthidae & Parika scaber & 36 & 0.14 & 3.8 & 3 & 0.1 & 4.2 \\
\hline & Unknown 3 & 2 & 0.01 & 0.5 & - & - & - \\
\hline & Unknown 12 & 3 & 0.01 & 0.5 & - & - & - \\
\hline & Unknown 20 & 1 & 0.003 & 0.2 & - & - & - \\
\hline & Damaged & 124 & 0.44 & 13.1 & 6 & 0.2 & 8.3 \\
\hline Total & & 28638 & & & 2538 & & \\
\hline
\end{tabular}


Table 3. Life-history characteristics of 11 common taxa collected in perpendicular-to-shore and parallel-to-shore samples. Habitat occupied by the adults and their mode of spawning are indicated. Habitats = IP: inshore pelagic; F: freshwater and estuaries; R: rocky reef; S: sand. Mode of spawning = P: pelagic eggs; FD: freshwater demersal eggs then marine larvae; $\mathrm{D}$ : demersal eggs; V: viviparous

\begin{tabular}{|c|c|c|c|c|}
\hline Family & Taxon & Adult & Spawning & Source \\
\hline Clupeidae & Sprattus spp. & IP & $\mathrm{P}$ & Ayling \& Cox (1987) \\
\hline Retropinnidae & Unidentified retropinnid & $\mathrm{IP}, \mathrm{F}$ & FD & McDowall (1990) \\
\hline Galaxiidae & Unidentified galaxiid & $\mathrm{F}$ & FD & McDowall (1990) \\
\hline Scorpaenidae & Unidentified scorpaenid & $\mathrm{R}$ & $\mathrm{P}, \mathrm{V}$ & Ayling \& Cox (1987) \\
\hline Mugilidae & Aldrichetta forsteri & IP, F & $\mathrm{P}$ & McDowall (1990) \\
\hline \multirow[t]{5}{*}{ Tripterygiidae } & Unidentified tripterygiid & $\mathrm{R}$ & $\mathrm{D}$ & Crossland (1981) \\
\hline & Forsterygion spp. & $\mathrm{R}$ & $\mathrm{D}$ & Crossland (1981) \\
\hline & Gilloblennius tripennis & $\mathrm{R}$ & $\mathrm{D}$ & Crossland (1981) \\
\hline & Grahamina capito & $\mathrm{R}$ & $\mathrm{D}$ & Crossland (1981) \\
\hline & Ruanoho decemdigitatus & $\mathrm{R}$ & $\mathrm{D}$ & Crossland (1981) \\
\hline Pleuronectidae & Rhombosolea plebeia & $\mathrm{S}, \mathrm{F}$ & $\mathrm{P}$ & Ayling \& Cox (1987) \\
\hline
\end{tabular}

Table 4. Summary of ANOVA of abundance of 11 common taxa with time and distance from shore as factors. Variance (\%) has been partitioned. ${ }^{* * *} \mathrm{p}<0.001$. Also shown is summary of post-hoc comparisons of mean abundance between stations nearshore $(0.05 \mathrm{~km})$ and further from shore $(2,4$ and $6 \mathrm{~km})$. More, ns, Less: number of occasions when significantly (Tukey HSD, p < 0.05) more larvae were found at $0.05 \mathrm{~km}$ than at 1 or more of the other stations, when there was no significant difference, and when fewer larvae were found at $0.05 \mathrm{~km}$, respectively

\begin{tabular}{|c|c|c|c|c|c|c|c|c|c|c|c|c|c|c|}
\hline \multirow[t]{2}{*}{ Taxon } & \multicolumn{3}{|c|}{ - Time -} & \multirow{2}{*}{$\overline{\mathrm{df}}$} & \multicolumn{2}{|c|}{ - Distance - } & \multicolumn{3}{|c|}{ — Interaction- } & \multicolumn{2}{|c|}{ Residual } & \multirow[t]{2}{*}{ More } & \multirow[t]{2}{*}{$\mathrm{ns}$} & \multirow[t]{2}{*}{ Less } \\
\hline & $\mathrm{df}$ & $F$ & $\%$ & & $F$ & $\%$ & $\mathrm{df}$ & $F$ & $\%$ & df & $\%$ & & & \\
\hline Sprattus spp. & 22 & $8.4^{* * *}$ & 34 & 3 & $7.6^{* * *}$ & 4 & 66 & $2.4^{* * *}$ & 29 & 184 & 33 & 0 & 21 & 2 \\
\hline Unidentified retropinnid & 20 & $13.7^{* * *}$ & 17 & 3 & $215.9^{* * *}$ & 41 & 60 & $8.2^{* * *}$ & 31 & 168 & 11 & 11 & 10 & 0 \\
\hline Unidentified galaxiid & 24 & $11.5^{* * *}$ & 34 & 3 & $26.2^{* * *}$ & 10 & 72 & $3.5^{* * *}$ & 31 & 200 & 25 & 0 & 21 & 4 \\
\hline Unidentified scorpaenid & 23 & $47.9^{* * *}$ & 60 & 3 & $25.7^{* * *}$ & 4 & 69 & $6.8^{* * *}$ & 26 & 192 & 10 & 3 & 20 & 1 \\
\hline Aldrichetta forsteri & 16 & $24.1^{* * *}$ & 55 & 3 & $6.5^{* * *}$ & 3 & 48 & $3.2^{* * *}$ & 22 & 136 & 20 & 0 & 15 & 2 \\
\hline Unidentified tripterygiid & 31 & $37.9^{* * *}$ & 52 & 3 & $18.6^{* * *}$ & 3 & 93 & $8.1^{* * *}$ & 34 & 256 & 11 & 1 & 25 & 6 \\
\hline Forsterygion spp. & 27 & $75.1^{* * *}$ & 63 & 3 & $36.5^{* * *}$ & 3 & 81 & $10.8^{* * *}$ & 27 & 224 & 7 & 3 & 17 & 8 \\
\hline Gilloblennius tripennis & 22 & $35.2^{* * *}$ & 55 & 3 & $11.0^{* * *}$ & 2 & 66 & $6.5^{* * *}$ & 30 & 184 & 13 & 1 & 19 & 3 \\
\hline Grahamina capito & 22 & $63.5^{* * *}$ & 51 & 3 & $42.0^{* * *}$ & 5 & 66 & $15.3^{* * *}$ & 37 & 184 & 7 & 0 & 11 & 12 \\
\hline Ruanoho decemdigitatus & 26 & $25.7^{* * *}$ & 48 & 3 & $1.3^{\mathrm{ns}}$ & 0 & 78 & $6.6^{* * *}$ & 37 & 216 & 15 & 2 & 20 & 5 \\
\hline Rhombosolea plebeia & 21 & $3.4^{* * *}$ & 48 & 3 & $22.5^{* * *}$ & 13 & 63 & $3.1^{* * *}$ & 39 & 176 & 34 & 4 & 18 & 0 \\
\hline
\end{tabular}

September (Robertson 1980). The occurrence of Sprattus spp. larvae in this study corresponds well with these observations.

Aldrichetta forsteri larvae were found from midsummer until midway through the following winter (Fig. 2b). They were more abundant at $2 \mathrm{~km}$ in February of both years, but generally there were few differences between stations (Table 4). There was no consistent pattern in the alongshore distribution of $A$. forsteri (Fig. 2b). Small $A$. forsteri larvae ( $3 \mathrm{~mm}$ ) appeared in late January and the mean size of larvae at most stations increased until late July (Fig. 3b). Older (larger) A. forsteri larvae were scarce further from shore (Fig. 3b, Table 5).

Spawning of Aldrichetta forsteri in central New Zealand has been observed from late December to mid-March (Manikiam 1963). The restricted temporal occurrence of small $A$. forsteri larvae in this study corresponds well with this observation. However, there is no evidence of the biennial spawning, with peaks in winter and summer, that has been observed in a South Island estuary (Webb 1973).

Rhombosolea plebeia larvae were found throughout most of the year (Fig. 2c), and often were less abundant further from shore (Table 4). There was no consistent pattern in the alongshore distribution of $R$. plebeia larvae (Fig. 2c). Small $R$. plebeia larvae (2.5 mm) appeared at various times throughout the year, and consequently there was no clear pattern in the size of larvae through time (Fig. 3c).

Rhombosolea plebeia appear to spawn throughout most of the year on the east coast of the North Island (Colman 1973) and South Island (Webb 1973), with a peak during August and September in Canterbury (Mundy 1968). The extended period over which small $R$. plebeia larvae were found in this study corresponds well with these spawning observations.

Larvae from the viviparous taxon (unidentified scorpaenids) were found from mid-spring until the end of 
Fig. 2. Temporal and spatial distribution of larvae from 3 pelagic spawners and 1 viviparous taxon at 4 perpendicular-to-shore stations $(0.05,2,4$ and $6 \mathrm{~km})$ between September 1995 and May 1997 and 4 parallel-to-shore stations $(0.05,0.1,0.3$ and $1 \mathrm{~km})$ between January 1997 and April 1997. (a) Sprattus spp.; (b) Aldrichetta forsteri; (c) Rhombosolea plebeia; (d) unidentified scorpaenids. Area of a circle is proportional to mean abundance of larvae in the 3 replicate plankton tows. Sampling occasions are indicated by a dot immediately above the $x$-axis. Scale is inset in upper graph. Open circles indicate overlapping data points
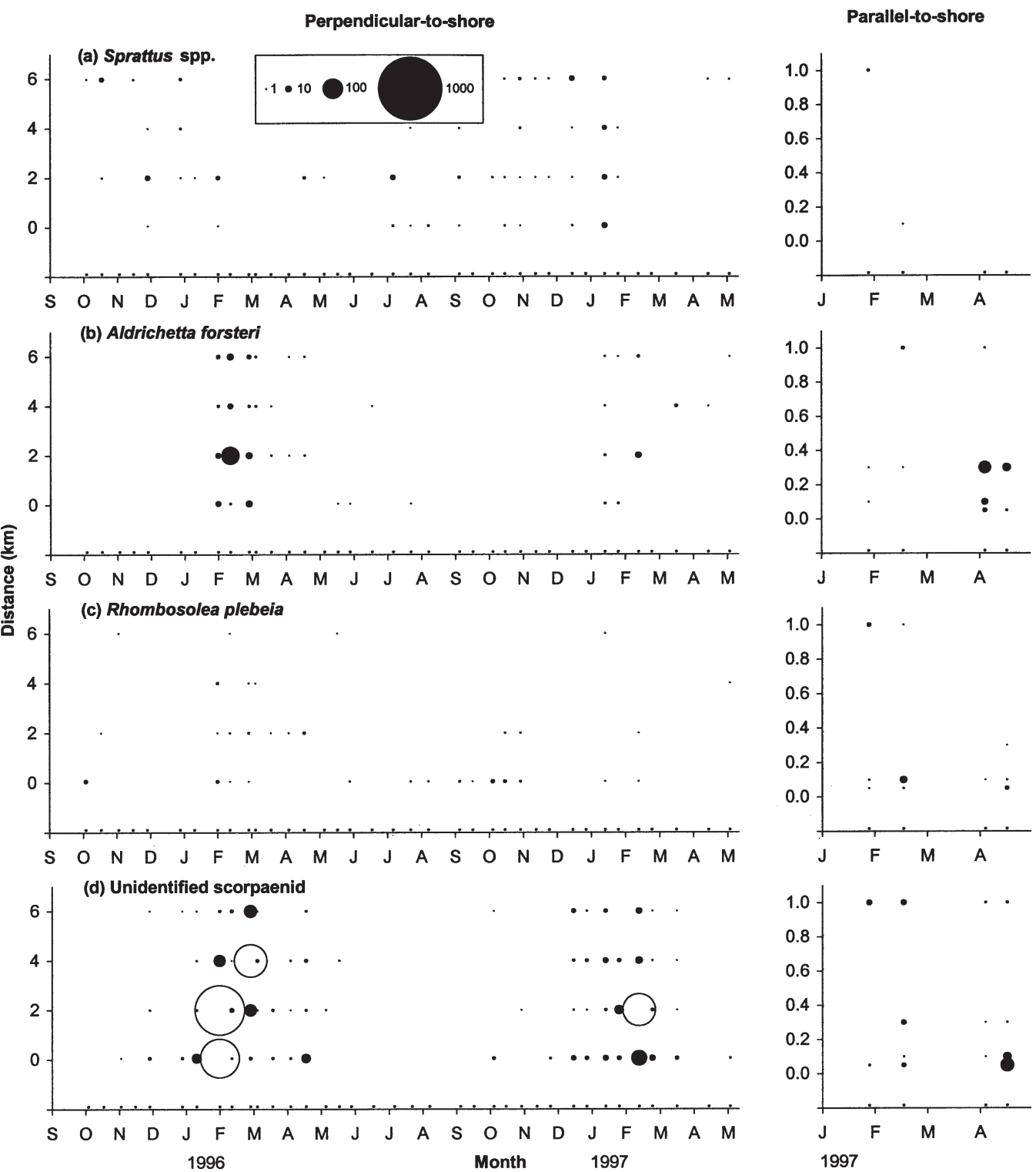

the following autumn (Fig. 2d), but relatively few larvae were found at $6 \mathrm{~km}$. There was no consistent pattern in the abundance of scorpaenid larvae with distance alongshore. Small larvae $(1.5 \mathrm{~mm})$ appeared in October, but there was little change in the mean size of larvae between October and May (Fig. 3d). Larger scorpaenid larvae (>8 mm) were collected only during January and February. The protracted period over which small unidentified scorpaenid larvae were found in this study is consistent with the extended spawning season observed by Francis (1988) for Helicolenus percoides, and the unidentified scorpaenid larvae most probably belong to this species.

The 2 common taxa that produced freshwater demersal eggs had very different offshore and alongshore larval distributions (Fig. 4). Unidentified retropinnid larvae were found from mid-summer until mid-winter (Fig. 4a). They occurred mostly nearshore with, on average, 10 times more larvae being collected at $0.05 \mathrm{~km}$ (Table 4). There was no consistent pattern in the alongshore distribution of retropinnid larvae (Fig. 4a). Small larvae $(6.5 \mathrm{~mm})$ appeared in January, and the mean size of larvae increased until June (Fig. 5a). Small larvae appeared again in mid-June (particularly at the stations furthest from shore), suggesting a second spawning event. Older (larger) retropinnid larvae were scarce further from shore during late autumn and winter (Fig. 4a, Table 5). Very small larvae $(<10 \mathrm{~mm})$ were abundant in late summer at the 2 parallel-to-shore stations closest to the Kowhai River mouth (Fig. 6).

The 2 New Zealand smelt species Retropinna retropinna and Stokellia anisodon have a long spawning 


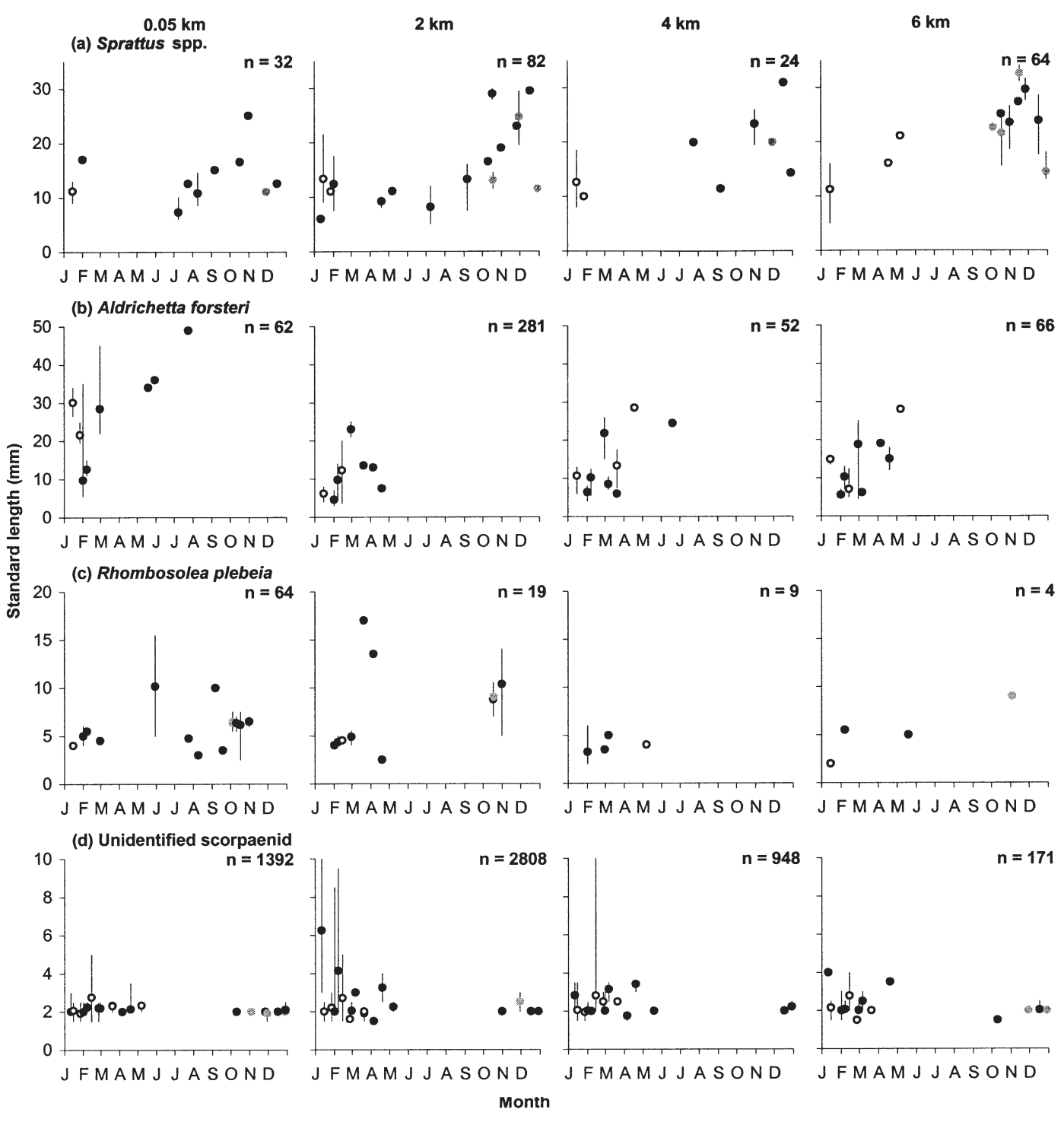

Fig. 3. Mean standard length and size range of (a) Sprattus spp.; (b) Aldrichetta forsteri; (c) Rhombosolea plebeia; (d) unidentified scorpaenid larvae at 4 perpendicular-to-shore stations $(0.05,2,4$ and $6 \mathrm{~km}$ ) between September 1995 and May 1997. Sampling dates from each year were converted to Julian days and are plotted jointly (1995: ; 1996: -; 1997: 0)

Table 5. Summary of ANOVA of standard length of 11 common taxa with distance from shore as a factor, and of ANOVA of standard length with distance alongshore from a rocky reef environment as a factor. ${ }^{*} \mathrm{p}<0.05 ;{ }^{* *} \mathrm{p}<0.01{ }^{* * *} \mathrm{p}<0.001$. Means $(\mathrm{mm})$ are given for each taxon at each station. Means that have different Greek letters are significantly different (Tukey HSD, $\mathrm{p}<0.05)$

\begin{tabular}{|c|c|c|c|c|c|c|c|c|c|c|c|c|}
\hline \multirow{2}{*}{ Taxon } & \multicolumn{6}{|c|}{ Perpendicular-to-shore } & \multicolumn{6}{|c|}{ _ Parallel-to-shore } \\
\hline & Residual df & $F$ & 0.05 & 2 & 4 & 6 & Residual df & $F$ & 0.05 & 0.1 & 0.3 & 1 \\
\hline Sprattus spp. & 198 & $20.56^{* * *}$ & $11.7^{\alpha}$ & $14.7^{\alpha}$ & $15.8^{\alpha}$ & $21.0^{\beta}$ & - & - & - & 9.5 & - & 34.9 \\
\hline Unidentified retropinnid & 1156 & $48.25^{* * *}$ & $26.4^{\alpha}$ & $22.1^{\beta}$ & $20.9^{\beta}$ & $19.9^{\beta}$ & 1694 & $26.99^{* * *}$ & $25.1^{\alpha}$ & $25.1^{\alpha}$ & $23.2^{\beta}$ & $21.1^{\gamma}$ \\
\hline Unidentified galaxiid & 376 & $3.37^{*}$ & $21.1^{\alpha \beta}$ & $18.6^{\alpha}$ & $20.1^{\alpha \beta}$ & $22.7^{\beta}$ & - & - & - & - & - & 9.5 \\
\hline Unidentified scorpaenid & 5316 & $30.94^{\mathrm{ns}}$ & 2.1 & 2.2 & 2.1 & 2.1 & 154 & $11.63^{* * *}$ & $2.5^{\alpha}$ & $2.3^{\alpha}$ & $2.3^{\alpha \beta}$ & $2.1^{\beta}$ \\
\hline Aldrichetta forsteri & 457 & $48.25^{* * *}$ & $22.1^{\alpha}$ & $11.1^{\beta}$ & $12.1^{\beta}$ & $11.5^{\beta}$ & 164 & $52.07^{* * *}$ & $26.1^{\alpha}$ & $25.5^{\alpha}$ & $27.9^{\alpha}$ & $12.1^{\beta}$ \\
\hline Unidentified tripterygiid & 5069 & $65.62^{* *}$ & $7.1^{\alpha}$ & $7.0^{\alpha}$ & $7.2^{\alpha}$ & $7.8^{\beta}$ & 77 & $14.76^{* * *}$ & $11.5^{\alpha}$ & $5.7^{\alpha}$ & $17.3^{\beta}$ & $14.3^{\gamma}$ \\
\hline Forsterygion spp. & 4049 & $54.82^{* *}$ & $12.1^{\alpha}$ & $9.9^{\beta}$ & $8.5^{\alpha}$ & $10.2^{\beta}$ & 126 & $2.90^{*}$ & $16.2^{\alpha}$ & $12.1^{\beta}$ & $17.6^{\alpha}$ & $17.9^{\alpha}$ \\
\hline Gilloblennius tripennis & 2142 & $11.17^{* * *}$ & $9.0^{\alpha}$ & $10.3^{\beta}$ & $10.1^{\beta}$ & $10.5^{\gamma}$ & - & - & 7.1 & - & 4.9 & - \\
\hline Grahamina capito & 6064 & $57.75^{* *}$ & $8.4^{\alpha}$ & $7.2^{\beta}$ & $7.6^{\gamma}$ & $8.0^{\delta}$ & 41 & $1.54^{\mathrm{ns}}$ & 14.4 & 13.3 & 16.3 & 13.0 \\
\hline Ruanoho decemdigitatus & 649 & $4.09^{* *}$ & $7.2^{\alpha}$ & $6.5^{\alpha \beta}$ & $5.9^{\beta}$ & $6.4^{\alpha \beta}$ & - & - & $\begin{array}{r}14.4 \\
3.6\end{array}$ & 14.5 & 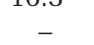 & 6.8 \\
\hline Rhombosolea plebeia & 92 & $3.90^{*}$ & $6.3^{\alpha}$ & $7.1^{\alpha}$ & $3.5^{\beta}$ & $5.3^{\alpha}$ & $37 \quad 1$ & $127.13^{* * *}$ & $4.6^{\alpha}$ & $5.2^{\alpha}$ & $16.0^{\beta}$ & - \\
\hline
\end{tabular}


Fig. 4. Temporal and spatial distribution of larvae of 2 freshwater demersal spawners at 4 perpendicular-to-shore stations and 4 parallel-to-shore stations. (a) Unidentified retropinnid; (b) unidentified galaxiid. Stations, dates and symbols as in Fig. 2
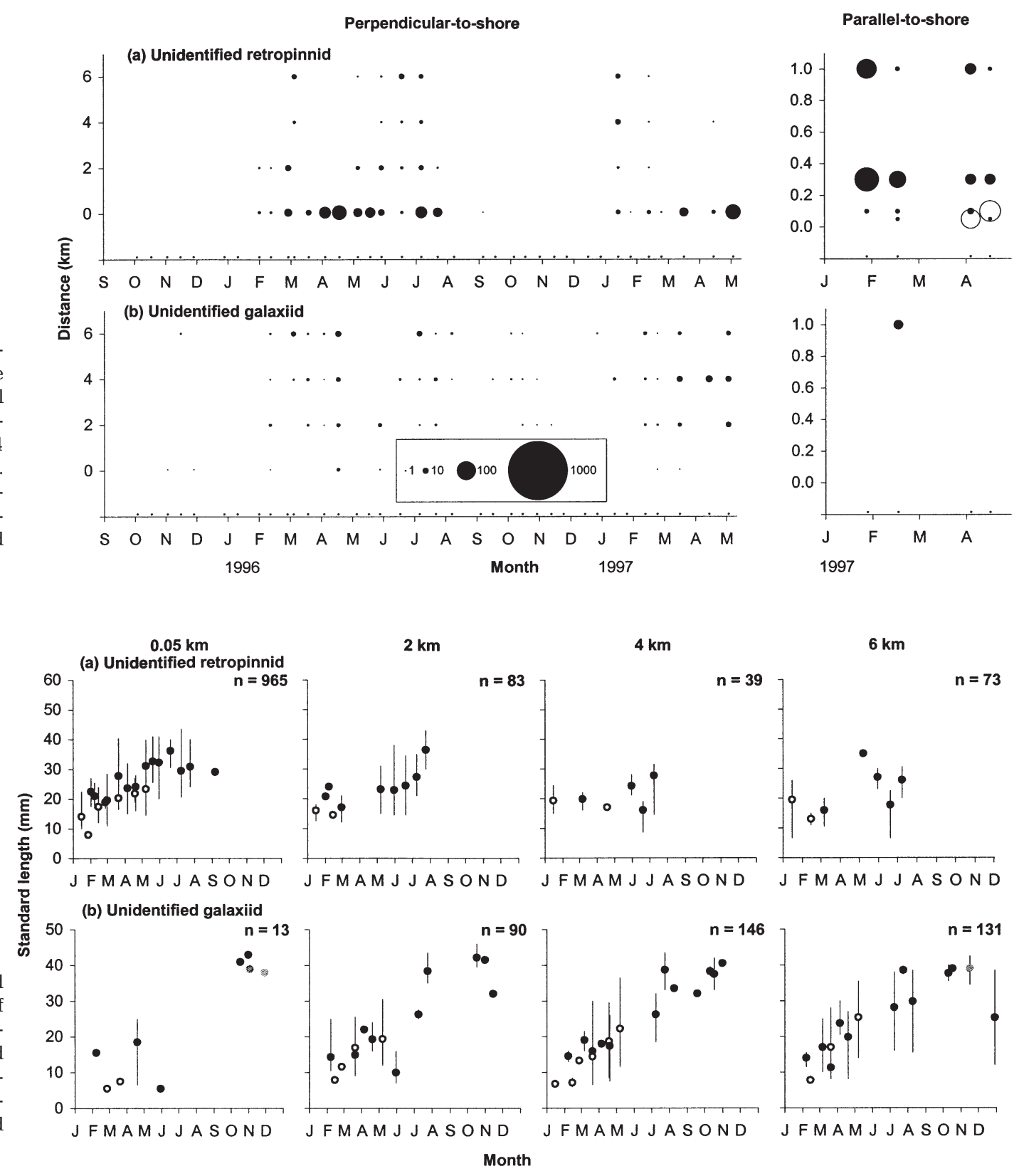

Fig. 5. Mean standard length and size range of (a) unidentified retropinnid; (b) unidentified galaxiid larvae at 4 perpendicular-to-shore stations. Stations, dates and symbols as in Fig. 3 season, extending from September to April (McDowall 1990), with a peak during the summer months (McMillan 1961). The presence of very small larvae at $6 \mathrm{~km}$ in late June, coupled with an egg development time of between 8 and 21 d (McMillan 1961), suggests that some spawning must still be occurring on the east coast of the South Island in at least late May.

Unidentified galaxiid larvae were found throughout most of the year (Fig. 4b). They were most abundant further from shore, with relatively few larvae collected at $0.05 \mathrm{~km}$. Galaxiid larvae were caught only at the parallel-to-shore sampling station adjacent to the Kowhai River mouth (Fig. 4b). Small larvae (6 mm) ap- peared in late January, and their mean size increased until May (Fig. 5b). Small larvae appeared again in late May, suggesting a second spawning event. The relationship between length and month of capture was consistent with that reported in another study of galaxiid dispersal in the marine environment (McDowall et al. 1975). Larvae collected at $0.05 \mathrm{~km}$ were highly variable in size, with some of the largest and smallest galaxiid larvae being collected there. The larvae collected at the parallel-to-shore sampling station adjacent to the Kowhai River mouth were all small (<11 mm).

The amphidromous galaxiid species Galaxias argenteus, G. fasciatus, G. postvectis, G. brevipinnis and G. 


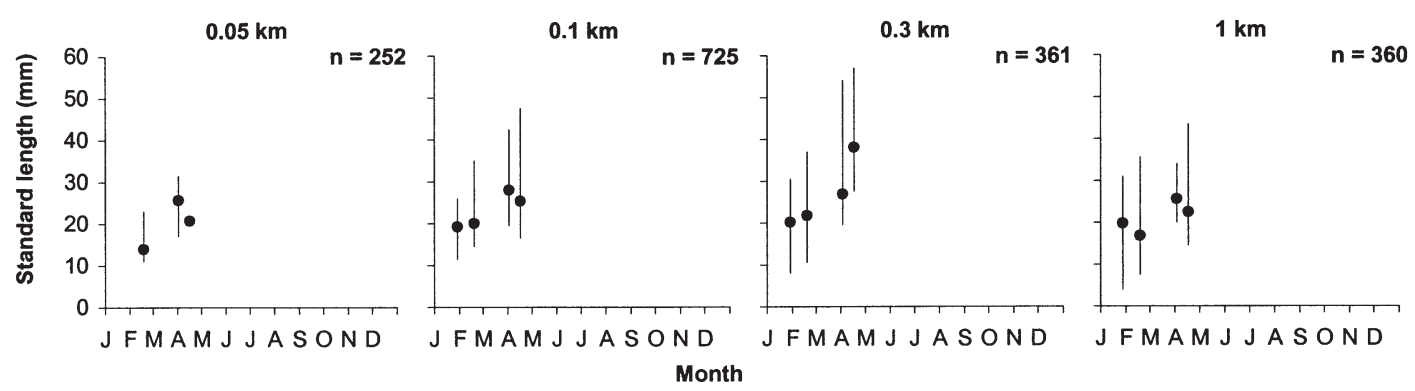

Fig. 6. Mean standard length and size range of unidentified retropinnid larvae at 4 parallel-to-shore stations $(0.05,0.1,0.3$ and $1 \mathrm{~km}$ ) between January and April 1997

Perpendicular-to-shore

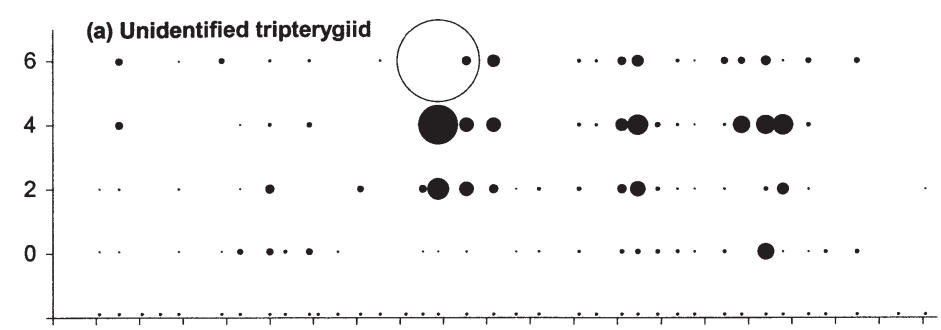

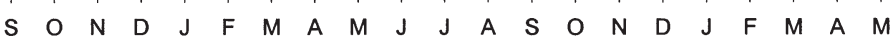
(b) Forsterygion spp.

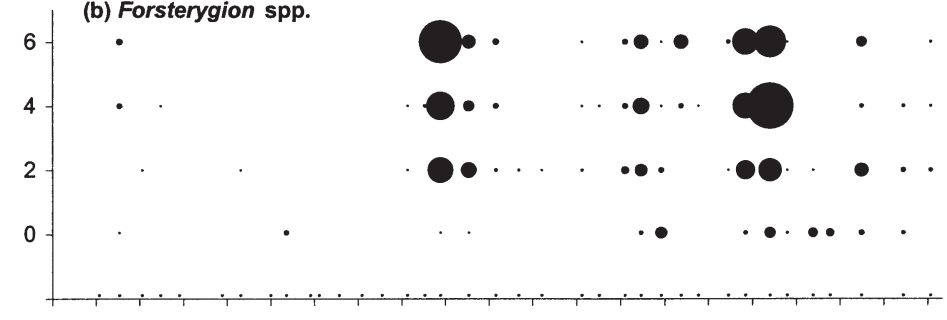

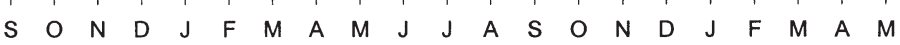

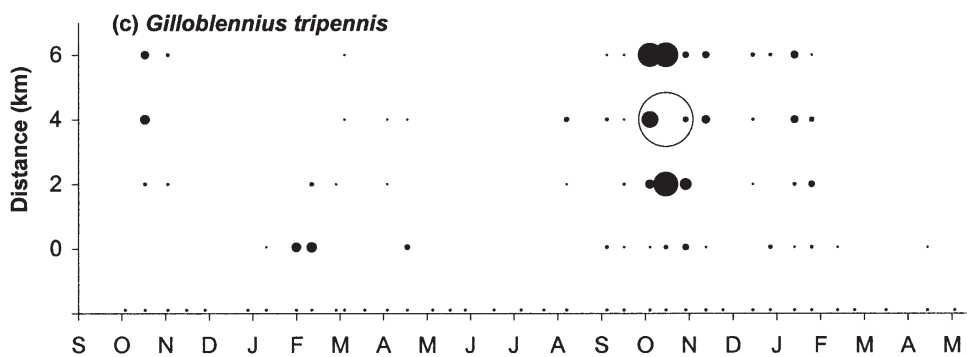

(d) Grahamina capito

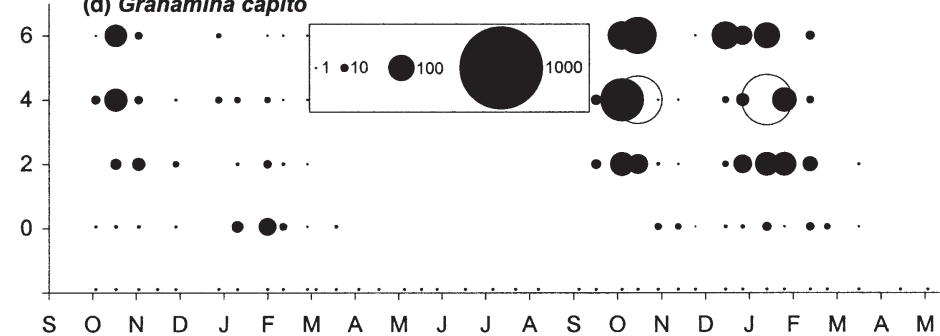

(e) Ruanoho decemdigitatus

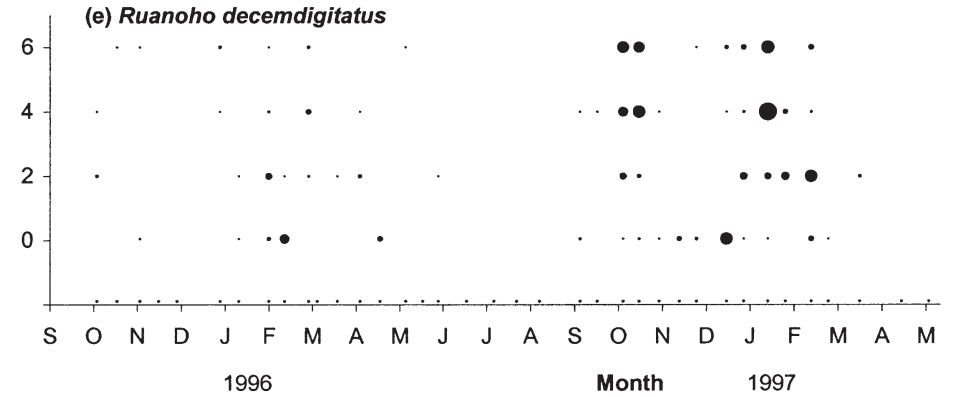

Parallel-to-shore
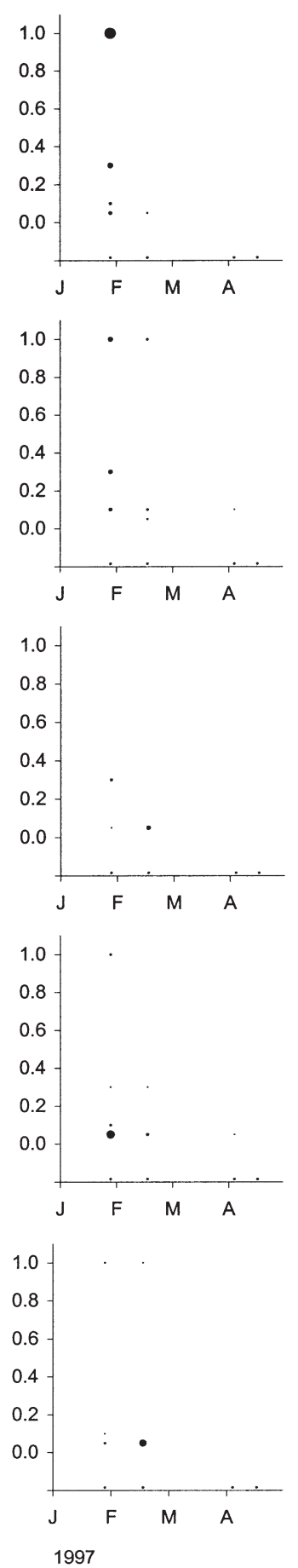

Fig. 7. Temporal and spatial distribution of larvae from 5 demersal spawners at 4 perpendicular-to-shore stations and 4 parallel-to-shore stations. (a) Unidentified tripterygiid; (b) Forsterygion spp.; (c) Gilloblennius tripennis; (d) Grahamina capito; (e) Ruanoho decemdigitatus. Stations, dates and symbols as in Fig. 2 

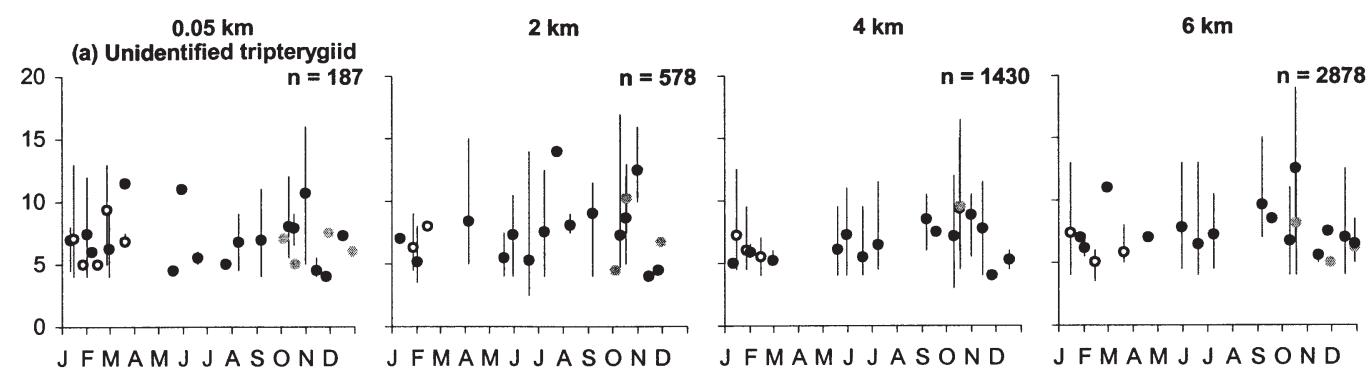

(b) Forsterygion spp.
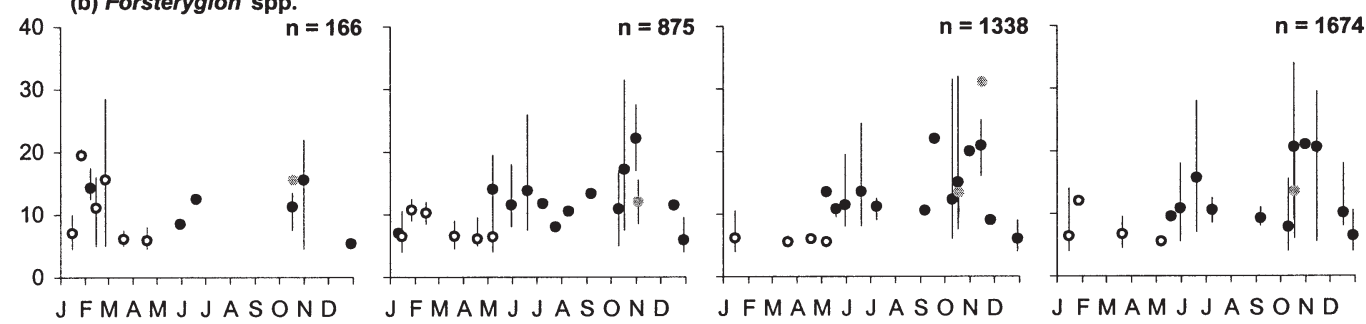

(c) Gilloblennius tripennis
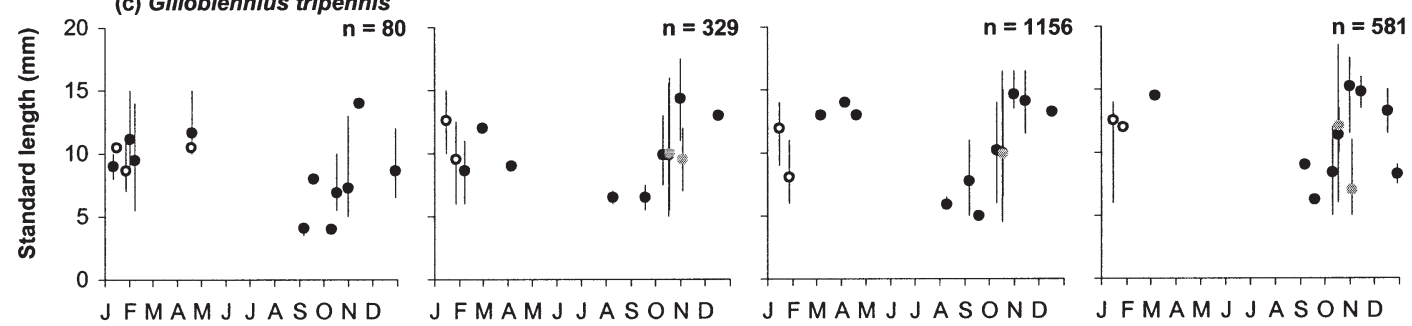

(d) Grahamina capito

Fig. 8. Mean standard length and size range of (a) unidentified tripterygiid, (b) Forsterygion spp., (c) Gilloblennius tripennis,

(d) Grahamina capito;

(e) Ruanoho decemdigitatus larvae at 4 perpendicular-to-shore stations. Stations, dates and symbols as in Fig. 3
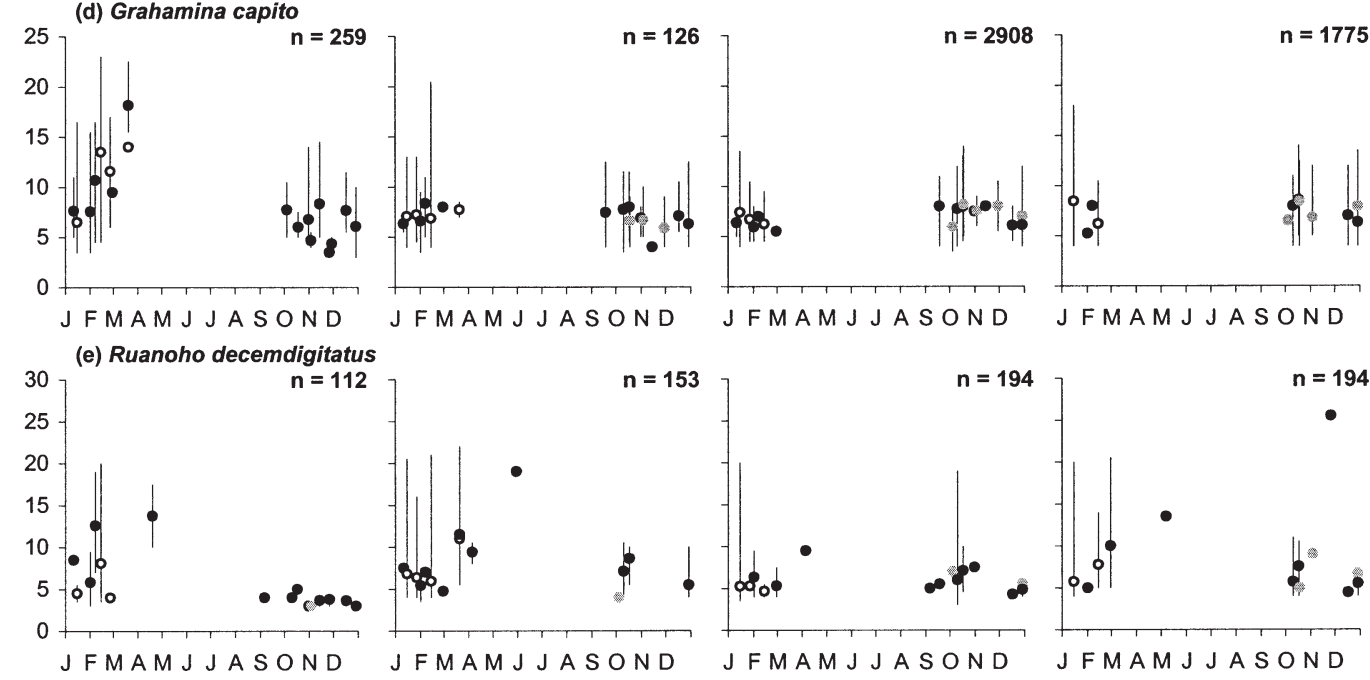

Month

maculatus all have extended spawning seasons that, between them, range from September through to June (McDowall 1990). However, most of these species have a spawning peak in autumn. The protracted period over which small galaxiid larvae were found is consistent with an extended spawning season, with pulses of newly hatched larvae obvious from January to late May (Fig. 5b).

The 5 tripterygiid taxa, which all produce marine demersal eggs, had differing larval distributions
(Fig. 7). Unidentified tripterygiid larvae were found throughout the year, with increased abundance during mid-winter, mid-spring and mid-summer (Fig. 7a). There was noticeable inter-annual variability in the abundance of unidentified tripterygiid larvae, with relatively few larvae being found during the first spring and summer of sampling. The larvae were often more abundant further from shore (Table 4), and the larvae at $6 \mathrm{~km}$ were slightly larger overall than those at the remaining stations (Table 5). There was no clear pat- 


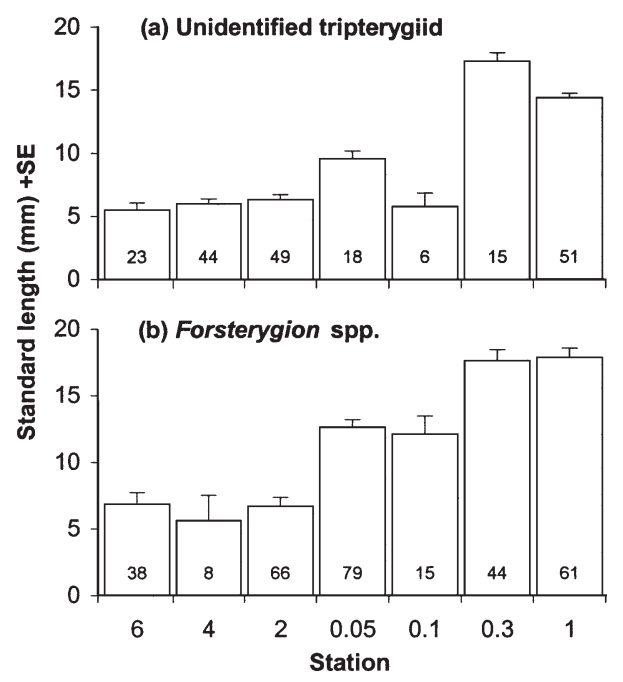

Fig. 9. Mean standard length of (a) unidentified tripterygiid and (b) Forsterygion spp. larvae caught during the same period (27 January 1997 to 18 April 1997) at 4 perpendicularto-shore stations $(0.05,2,4$ and $6 \mathrm{~km})$ and 4 parallel-to-shore stations $(0.05,0.1,0.3$ and $1 \mathrm{~km})$. Offshore and alongshore data for $0.05 \mathrm{~km}$ station have been combined. Sample sizes are given within each bar

tern in the mean sizes of larvae through time (Fig. 8a). This is probably a result of the multi-species composition of this taxon. The unidentified tripterygiid larvae at the parallel-to-shore sampling stations (except $0.1 \mathrm{~km})$ were larger on average $\left(F_{6,199}=86.42, \mathrm{p}<\right.$ 0.001 ) than those found further from shore during the same period (Fig. 9).

Forsterygion spp. larvae were found throughout the year, with increased abundance during mid-winter, midspring and mid-summer (Fig. 7b). There was noticeable inter-annual variability in the abundance of Forsterygion spp. larvae, with relatively few larvae being found during the first spring and summer of sampling. Forsterygion spp. larvae were often less abundant closer to shore (Table 4). However, the larvae found at $0.05 \mathrm{~km}$ had a larger mean size than those at the remaining stations (Fig. 8b). There was no consistent pattern in the alongshore distribution of Forsterygion spp. larvae. Small larvae $(4 \mathrm{~mm})$ appeared throughout autumn, mid-spring and mid-summer, with subsequent increases in their mean size. The Forsterygion spp. larvae at the parallelto-shore sampling stations were larger on average $\left(F_{6,304}=39.16, \mathrm{p}<0.001\right)$ than those found further from shore during the same period (Fig. 9).

Species in the Forsterygion genus spawn from May to November, with activity peaking in mid-winter (Ayling \& Cox 1987, Francis 1988, Paulin \& Roberts 1992). However, individuals may spawn several times throughout the season (Paulin \& Roberts 1992). The appearance of young larvae throughout much of the year is consistent with this extended spawning period.
Gilloblennius tripennis larvae were found from late winter to early autumn, with increased abundance in mid-spring and mid-summer (Fig. 7c). They were often less abundant closer to shore (Table 4), but were not found at the 2 parallel-to-shore stations furthest from the rocky reef environment (Fig. 7c). Small G. tripennis larvae $(4 \mathrm{~mm})$ appeared in August/September, particularly at $0.05 \mathrm{~km}$, and their mean size increased until March/April at most stations (Fig. 8c). There was a small increase in the mean size of larvae with distance from shore (Table 5). This was mainly due to the absence of very small larvae further from shore (Fig. 8c).

Gilloblennius tripennis spawn from July to September (Paulin \& Roberts 1992). The appearance of young larvae in early spring is consistent with this. However, the presence of young larvae in January/February (Fig. 8c) provides some evidence of a second spawning period during summer.

Grahamina capito larvae were found from early spring until late summer, with increased abundance in mid-spring and mid-summer (Fig. 7d). They were usually less abundant closer to shore (Table 4). However, the few larvae that were caught at $0.05 \mathrm{~km}$ were larger on average than those at the other stations (Table 5). Small larvae $(3.5 \mathrm{~mm})$ initially appeared in September, but there was no clear increase in the average size of larvae until after the final influx of small larvae in January/February (Fig. 8d). G. capito larvae were more abundant at the parallel-to-shore station that was closest to the rocky reef environment (Fig. 7d), but there was no significant difference among the parallelto-shore stations in the mean size of larvae (Table 5).

Grahamina capito have a long spawning period, extending from June to January with activity peaking in August to September (Ayling \& Cox 1987, Francis 1988). The appearance of young larvae from midspring to mid-summer is consistent with this extended spawning period.

Ruanoho decemdigitatus larvae were found from early spring to late autumn, with increased abundance in mid-spring and mid-summer (Fig. 7e). They were often less abundant closer to shore (Table 4). Overall, larvae were generally the same size at all stations, but larger larvae were slightly more abundant at $0.05 \mathrm{~km}$ during autumn (Fig. 8e, Table 5). Small larvae (3.5 mm) appeared throughout much of spring and summer, and consequently there was no clear increase in the average size of larvae until after the final influx of small larvae in February (Fig. 8e). There was no consistent pattern in the alongshore distribution of $R$. decemdigitatus larvae.

Ruanoho decemdigitatus spawn from June to October (Francis 1988), with most eggs being laid during winter (Paulin \& Roberts 1992). The appearance of 
young larvae in early spring is consistent with this, but the presence of young larvae in January/February (Fig. 8e) provides some evidence of a second spawning period during summer.

\section{DISCUSSION}

The ichthyoplankton collected during this study reflect the diverse fish fauna in the Kaikoura region. Oceanic currents and the nearby Kaikoura Canyon contribute oceanic and deep-dwelling species to the large array of coastal and reef fish species. However, most of the 60 taxa collected during this study were relatively rare. This apparent rarity may be real or it may be a consequence of the sampling procedure. The abundance of taxa that do not commonly inhabit the neuston layer will be underestimated by the sampling protocols used in this study. Furthermore, the abundance of a taxon that occurred in a temporal pulse on a scale finer than that which was sampled would also be underestimated. However, 11 taxa were sufficiently common in the samples to allow analysis of the temporal and spatial patterns in their abundance.

The temporal distributions of larvae of the $11 \mathrm{com}$ mon taxa corresponded well with existing data on adult spawning efforts. Fine-scale temporal data on egg production does not exist for any of the common taxa on the east coast of the South Island, but in most instances larval abundance patterns matched previously reported spawning periods. The major discrepancies observed were the lack of evidence of winter spawning in Aldrichetta forsteri and the longer than expected spawning period of retropinnids. Also, the reappearance in late summer of small larvae of 2 species with late winter/spring spawning (Gilloblennius tripennis and Ruanoho decemdigitatus) suggests that these species may have a second spawning event in summer.

The temporal distribution patterns of larvae of most of the common taxa corresponded well with previously described patterns of primary and zooplankton production in the Kaikoura region. Bradford (1972) found that phytoplankton production (chlorophyll a) peaked during September, with a smaller, less-defined peak in late February. Copepod numbers also peaked in September and late February (Bradford 1972). The increased abundance of larvae in early spring and late summer is typical of many temperate regions, with reproductive efforts matched to periods of increased primary production that are brought on by increased water temperatures and wind-mixing.

Many studies have shown that the abundance of ichthyoplankton varies with distance from shore (Koubbi et al. 1991, Suthers \& Frank 1991, Boehlert \&
Mundy 1994, MacGregor \& Houde 1996, Grioche \& Koubbi 1997). In our study, the greatest abundances of fish larvae were found further from shore (4 and $6 \mathrm{~km}$ ). The most common taxa further from shore included deep-water species (Gymnoscopelus piabilis), freshwater species (galaxiids) and several intertidal/reef species (Bovichtus variegatus and most of the tripterygiids). Other taxa showed no clear pattern with distance from shore (Sprattus spp. and Ruanoho decemdigitatus) or were more abundant closer to shore (retropinnids, scorpaenids, Aldrichetta forsteri and Rhombosolea plebeia). The results of our study show that the abundance of most taxa, for at least part of the year, does vary with distance from shore. However, in many cases the distribution patterns contradict those previously reported for species with similar modes of spawning.

Several studies have found that larvae that are more abundant nearshore hatch from non-pelagic eggs, whereas those that are more widely distributed are generally derived from pelagic eggs (Leis \& Miller 1976, Marliave 1986, Kingsford \& Choat 1989, Suthers \& Frank 1991, Brogan 1994, Gray 1998). The nearshore abundance of larvae hatched from non-pelagic eggs is thought to be due to the absence of passive drift during the egg phase. While the data presented in this study support these patterns for some taxa (e.g. scorpaenids are viviparous and their larvae were more abundant closer to shore while Sprattus spp. and Aldrichetta forsteri have pelagic eggs and their larvae were widely dispersed), others do not follow the patterns observed elsewhere. Most of the taxa (the galaxiids and tripterygiids) that hatch from demersal eggs were also widely dispersed. Conversely, Rhombosolea plebeia, which have pelagic eggs, were more abundant nearshore. For the taxa in this study, we reject the hypothesis that reef fish larvae that hatch from non-pelagic eggs are retained mostly or exclusively near reefs on an exposed coast.

Greater numbers of tripterygiid larvae, which are almost exclusively reef-dwelling species as adults, are often found at nearshore sites (Leis \& Miller 1976, Leis 1982, Gray 1993), particularly in the vicinity of reefs (Leis \& Goldman 1984, Kingsford \& Choat 1989, Brogan 1994). However, in our study, most taxa within the family Tripterygiidae showed equal if not greater abundance further from shore. Additionally, tripterygiid larvae of all sizes ( 3 to $32 \mathrm{~mm}$ ) were found further from shore. Clearly, the data in our study do not support the assertion that tripterygiid larvae are more abundant nearshore. Although this pattern is robust for our study, results may be influenced by the time and method of sampling.

Tricklebank et al. (1992) alluded to the influence of sampling season on estimates of the nearshore-off- 
shore distribution of tripterygiid larvae. Researchers who sampled only during spring or summer (e.g. Leis 1982, Leis \& Goldman 1984, Kingsford \& Choat 1989) found highest abundances of tripterygiid larvae nearshore, but winter samples on similar spatial scales (and in the case of Kingsford \& Choat 1989 in the same location) contained much greater numbers of tripterygiid larvae, and these were mostly further from shore (Tricklebank et al. 1992). The data in our study support this pattern, with very large numbers of tripterygiid larvae being found in mid-winter samples, particularly further from shore. However, some nearshore summer samples (particularly January/February 1996) contained greater abundances of tripterygiid larvae (especially Gilloblennius tripennis, Grahamina capito and Ruanoho decemdigitatus) than the associated samples further from shore. If sampling had been done only at this time, therefore, a very different pattern of perpendicular-to-shore distribution would have been perceived.

Many of the studies reporting greater numbers of tripterygiid larvae inshore used oblique tows to sample ichthyoplankton (Leis 1982, Kingsford \& Choat 1989, Brogan 1994), while the only other study reporting greater numbers further from shore used surface tows (Tricklebank et al. 1992). It is likely that oblique tows underestimate the abundance of tripterygiid larvae further from shore and that surface tows underestimate the abundance of tripterygiid larvae at nearshore sites. For example, Kingsford (1988) found that oblique tows in deep water grossly underestimated (by a factor of up to 60) the abundance of tripterygiid larvae, because they are more abundant at the sea surface. In shallow water, however, tripterygiid larvae can occur throughout the water column (Kingsford 1988) and therefore may be sampled better by oblique rather than surface tows.

With an increased knowledge of, and thus an increased ability to identify, the larval stages of many species of temperate reef fishes, there is little benefit in ascribing distributional patterns to whole families. Several authors have reported inconsistencies within families in the distribution patterns attributed to the family as a whole. Tripterygiids and cottids have been described as having 'inshore' larvae (e.g. Leis \& Miller 1976, Gray 1993). However, Marliave (1986) found that the genus Artedius, within the family Cottidae, had an offshore distribution distinct from other members of the same family. Kingsford \& Choat (1989) and Tricklebank et al. (1992) reported inconsistencies in the Tripterygiidae, with larvae from the genus Forsterygion frequently being found further from shore. Although gobiids have been described as having 'inshore' larvae (e.g. Leis \& Miller 1976, Gray 1993), Brogan (1994) identified 2 possible groups: larvae that were concentrated over reefs, and larvae that were more abundant further from shore. These appeared to represent different species, although the taxonomy of the groups was not completely resolved. Speciesspecific patterns of offshore and alongshore distributions are undoubtedly masked by grouping families together. Some of these patterns may become clearer as more taxa are identified to species level and more becomes known about the life-history features and demographics of individual species.

The anadromous retropinnids occurred almost exclusively at the nearshore stations. This taxon's ability to maintain this distribution is most probably a result of its life history. Adult retropinnids spawn in rivers, releasing eggs that sink to the substrate (McDowall 1990). The eggs develop there and, after hatching, the larvae are carried out to sea by river currents. Larvae are about $5 \mathrm{~mm}$ in length when they hatch (McMillan 1961), so it is likely that by the time they reach the sea they are capable swimmers. It has been suggested that fish larvae that are larger at hatching and at a more advanced stage of development because of hatching from demersal eggs may be more capable of remaining within a given area by using their superior swimming and sensory abilities (Blaxter 1986, Miller et al. 1988, Suthers \& Frank 1991). For retropinnids, a lack of planktonic dispersal while in the egg phase coupled with a stronger swimming ability (Mitchell 1989) may allow them to restrict their distribution to nearshore areas.

The offshore distribution of the retropinnids contrasts markedly with that of the galaxiids. Like the retropinnids, galaxiid larvae hatch from demersal eggs in freshwater before entering the sea (McDowall 1990). Galaxiid larvae are also relatively large 7 to $9 \mathrm{~mm}$ ) when they enter the marine environment (McDowall 1990), and they too should be capable of maintaining a nearshore distribution. However, in this study, galaxiid larvae appeared to disperse widely, with few larvae occurring close to shore. The differing spatial distributions of these 2 families may reflect contrasting needs in terms of using the planktonic phase as a dispersal mechanism. The galaxiids, like the retropinnids, are diadromous. However, they are mostly amphidromous. The larvae of amphidromous species migrate to sea soon after hatching to feed and grow to a post-larval stage (McDowall 1998). Juveniles then migrate back into freshwater, where most somatic growth, as well as sexual maturation and reproduction, occurs (McDowall 1997). For anadromous species like the retropinnids, most feeding and growth is at sea prior to the migration of fully grown adult fish into freshwater to reproduce. Retropinnids are short-lived (1 to 2 yr) and can disperse widely both as juveniles and adults during their extended period at sea. Most of 
the amphidromous galaxiid species are much longerlived (up to 27 yr for Galaxias argenteus: Jellyman 1979), and are likely to use their planktonic phase as a dispersal mechanism so that post-larval stages can restore populations in perturbed river systems (McDowall 1995, 1996). The positioning of galaxiid ichthyoplankton further from shore aids in this dispersal (McDowall et al. 1975, McDowall 1990, Waters et al. 2000).

A notable feature of this and similar studies in New Zealand is the relative paucity in the plankton samples of larvae of prominent reef-dwelling fishes. Many species of Labridae, Cheilodactylidae and Odacidae inhabit rocky reefs in the Kaikoura region (Hickford \& Schiel 1995) and may have trophic effects on reef communities (Kingett \& Choat 1981, Jones 1984). In our study, no cheilodactylid or odacid larvae and only 20 labrid larvae were caught. This paucity may be a consequence of the relatively low numbers of adults overall compared to such taxa as retropinnids, scorpaenids and tripterygiids, but may also involve morphological, behavioural or sensory characteristics which make larvae from these families unlikely to be caught.

The origins of the reef fish and freshwater fish larvae that were found offshore from the Kaikoura coast are not clear. Some are likely to have come from the reefs and rivers around the Kaikoura Peninsula, but the Southland Current may have transported many from areas further to the south. Nevertheless, the presence of these larvae at the station furthest from shore is an indication that they have been dispersed at least $6 \mathrm{~km}$ from their natal environment and possibly a great deal further.

While the offshore movement of larvae is likely to aid in the alongshore dispersal of both reef and freshwater fish species, these larvae must eventually move closer to shore to settle successfully from their planktonic phase to a more sedentary existence on reefs or to migrate into rivers. Clearly, taxa such as the galaxiids and tripterygiids must move nearer to shore as they develop. There is evidence from several taxa in this study (unidentified retropinnids, Aldrichetta forsteri, Forsterygion spp. Grahamina capito, and Ruanoho decemdigitatus) of larger (and therefore older) larvae occurring closer to shore. These larger larvae are likely to be the few remaining survivors from the more abundant, but younger, larval assemblages seen further from shore.

The mechanisms of onshore transport of fish larvae in the Kaikoura region are not yet known, but may include internal waves (Kingsford \& Choat 1986), wind-derived water motion (Heath 1972b), or eddies (Lobel \& Robinson 1986). However, most of these transport mechanisms are inconsistent temporally and spatially in their occurrence (Kingsford 1990). So, while the offshore movement of larvae may aid in alongshore dispersal of larvae, it also exposes them to unfavourable advection, and as a result their recruitment is likely to be inconsistent (Suthers \& Frank 1991).

Larvae returning to the nearshore environment as a result of cross-shelf advection may still not encounter a suitable habitat for settlement. The large tripterygiid and Forsterygion spp. larvae that were found at the alongshore stations furthest from rocky reefs may have been transported alongshore directly from reef areas, or they may have arrived at these stations after first moving away from shore. Either way, to successfully recruit into the adult population, they are dependent on further alongshore movement to locate a reef habitat suitable for settlement. This movement may be facilitated by favourable alongshore currents or by active swimming. However, for larvae that are competent to settle, this delay will prolong their larval phase and expose them to further mortality.

Clearly, broad-scale dispersal of reef fish larvae, although possibly providing benefits in terms of predator avoidance (Johannes 1978), colonisation of patchy adult habitats (Barlow 1981) and risk-spreading (Doherty et al. 1985), does carry with it an increased risk of unfavourable advection that may delay or even prevent recruitment.

Acknowledgements. We thank Claus Bader, Chris Carter, Jo Davis and Craig Dolphin for assistance with field collections, Nick Etheridge for help with designing and constructing the plankton net, Jack van Berkel for logistic assistance, and the University of Canterbury for scholarship and research support. We thank 3 anonymous referees for constructive comments on this paper.

\section{LITERATURE CITED}

Ayling T, Cox GJ (1987) Collins guide to the sea fishes of New Zealand. William Collins Publishers, Auckland

Barlow GW (1981) Patterns of parental investment, dispersal and size among coral-reef fishes. Environ Biol Fish 6: 65-85

Black KP (1993) The relative importance of local retention and inter-reef dispersal of neutrally buoyant material on coral reefs. Coral Reefs 12:43-53

Black KP, Moran PJ, Hammond LS (1991) Numerical models show coral reefs can be self-seeding. Mar Ecol Prog Ser 74:1-11

Blaxter JHS (1986) Development of sense organs and behaviour of teleost larvae with special reference to feeding and predator avoidance. Trans Am Fish Soc 115:98-114

Boehlert GW, Mundy BC (1994) Vertical and onshore-offshore distributional patterns of tuna larvae in relation to physical habitat features. Mar Ecol Prog Ser 107:1-13

Bradford JM (1972) Systematics and ecology of New Zealand central east coast plankton sampled at Kaikoura. NZ Dep Sci Ind Res Bull 207 
Brogan MW (1994) Distribution and retention of larval fishes near reefs in the Gulf of California. Mar Ecol Prog Ser 115: $1-13$

Chiswell SM, Schiel DR (2001) Influence of along-shore advection and upwelling on coastal temperature at Kaikoura Peninsula, New Zealand. NZ J Mar Freshw Res 35: 307-317

Colman JA (1973) Spawning and fecundity of two flounder species in the Hauraki Gulf, New Zealand. NZ J Mar Freshw Res 7:21-43

Colman JA (1979) Spawning of the sprat, Sprattus antipodum (Hector), round the South Island of New Zealand. NZ J Mar Freshw Res 13:263-272

Crossland J (1981) Fish eggs and larvae of the Hauraki Gulf, New Zealand. NZ Minist Agric Fish Res Bull 23:1-61

Doherty PJ, Williams DM, Sale PF (1985) The adaptive significance of larval dispersal in coral reef fishes. Environ Biol Fish 12:81-90

Francis MP (1988) Coastal fishes of New Zealand: a diver's identification guide. Heinemann Reed, Auckland

Gray CA (1993) Horizontal and vertical trends in the distributions of larval fishes in coastal waters off central New South Wales, Australia. Mar Biol 116:649-666

Gray CA (1998) Diel changes in vertical distributions of larval fishes in unstratified coastal waters off southeastern Australia. J Plankton Res 20:1539-1552

Grioche A, Koubbi P (1997) A preliminary study of the influence of a coastal frontal structure on ichthyoplankton assemblages in the English Channel. ICES J Mar Sci 54:93-104

Heath RA (1972a) Oceanic upwelling produced by northerly winds on the north Canterbury coast, New Zealand. NZ J Mar Freshw Res 6:343-351

Heath RA (1972b) Wind-derived water motion off the east coast of New Zealand. NZ J Mar Freshw Res 6:352-364

Heath RA (1972c) The Southland Current. NZ J Mar Freshw Res 6:497-533

Hickford MJH, Schiel DR (1995) Catch vs count: effects of gill-netting on reef fish populations in southern New Zealand. J Exp Mar Biol Ecol 188:215-232

Hunter JR (1981) Feeding ecology and predation of marine fish larvae. In: Lasker R (ed) Marine fish larvae. Washington Sea Grant Program, Seattle, p 33-59

Jellyman DJ (1979) Observations on the biology of the giant kokupu, Galaxias argenteus (Gmelin, 1789). Mauri Ora 7 : 53-61

Johannes RE (1978) Reproductive strategies of coastal marine fishes in the tropics. Environ Biol Fish 3:65-84

Jones GP (1984) Population ecology of the temperate reef fish Pseudolabrus celidotus Bloch \& Schneider (Pisces: Labridae). II. Factors influencing adult density. J Exp Mar Biol Ecol 75:277-303

Kingett PD, Choat JH (1981) Analysis of density and distribution patterns in Chrysophrys auratus (Pisces, Sparidae) within a reef environment-an experimental approach. Mar Ecol Prog Ser 5:283-290

Kingsford MJ (1988) The early life history of fish in coastal waters of northern New Zealand: a review. NZ J Mar Freshw Res 22:463-479

Kingsford MJ (1990) Linear oceanographic features: a focus for research on recruitment processes. Aust J Ecol 15: 391-401

Kingsford MJ, Choat JH (1986) Influence of surface slicks on the distribution and onshore movements of small fish. Mar Biol 91:161-171

Kingsford MJ, Choat JH (1989) Horizontal distribution patterns of presettlement reef fish: are they influenced by the proximity of reefs? Mar Biol 101:285-297
Koubbi P, Ibanez F, Duhamel G (1991) Environmental influences on spatio-temporal oceanic distribution of ichthyoplankton around the Kerguelen Islands (Southern Ocean). Mar Ecol Prog Ser 72:225-238

Kuno E (1981) Dispersal and persistence of populations in unstable habitats: a theoretical note. Oecologia 49: $123-126$

Leis JM (1982) Nearshore distributional gradients of larval fish (15 taxa) and planktonic crustaceans (6 taxa) in Hawaii. Mar Biol 72:89-97

Leis JM, Goldman B (1984) A preliminary distributional study of fish larvae near a ribbon coral reef in the Great Barrier Reef. Coral Reefs 2:197-203

Leis JM, Miller JM (1976) Offshore distributional patterns of Hawaiian fish larvae. Mar Biol 36:359-367

Lobel PS, Robinson AR (1986) Transport and entrapment of fish larvae by mesoscale eddies and currents in Hawaiian waters. Deep-Sea Res 33:483-500

MacGregor JM, Houde ED (1996) Onshore-offshore pattern and variability in distribution and abundance of bay anchovy Anchoa mitchilli eggs and larvae in Chesapeake Bay. Mar Ecol Prog Ser 138:15-25

Manikiam JS (1963) Studies on the yellow-eye mullet, Aldrichetta forsteri (Cuv. and Val.) (Mugilidae). MSc thesis, Victoria University of Wellington, NZ

Marliave JB (1986) Lack of planktonic dispersal of rocky intertidal fish larvae. Trans Am Fish Soc 115: 149-154

McDowall RM (1990) New Zealand freshwater fishes: a natural history and guide. Heinemann Reed, Auckland

McDowall RM (1995) Seasonal pulses in migrations of New Zealand diadromous fish and the potential impacts of river mouth closure. NZ J Mar Freshw Res 29:517-526

McDowall RM (1996) Diadromy and the assembly and restoration of riverine fish communities: a downstream view. Can J Fish Aquat Sci 53:219-236

McDowall RM (1997) The evolution of diadromy in fishes (revisited) and its place in phylogenetic analysis. Rev Fish Biol Fish 7:443-462

McDowall RM (1998) Fighting the flow: downstream- upstream linkages in the ecology of diadromous fish faunas in west coast New Zealand rivers. Freshw Biol 40:111-122

McDowall RM, Robertson DA, Saito R (1975) Occurrence of galaxiid larvae and juveniles in the sea. NZ J Mar Freshw Res 9:1-9

McMillan HM (1961) An addition to the knowledge of the fish Retropinna anisodon Stockell (Retropinnidae). Trans R Soc NZ Zool 1:139-144

Metz JAJ, de Jong TJ, Klinkhamer PGL (1983) What are the advantages of dispersing; a paper by Kuno explained and extended. Oecologia 57:166-169

Miller TJ, Crowder LB, Rice JA, Marschall EA (1988) Larval size and recruitment mechanisms in fishes: toward a conceptual framework. Can J Fish Aquat Sci 45: 1657-1670

Mitchell CP (1989) Swimming performances of some native freshwater fishes. NZ J Mar Freshw Res 23:181-187

Mundy AR (1968) A study of the biology of the sand flounder Rhombosolea plebeia (Richardson) off the Canterbury coast. PhD thesis, University of Canterbury, NZ

Paulin CD, Roberts C (1992) The rockpool fishes of New Zealand. Southwestern Publishing, Auckland

Robertson DA (1980) Hydrology and quantitative distribution of planktonic eggs of some marine fishes of the Otago coast, south-eastern New Zealand. NZ Minist Agric Fish Res Bull 21:69

Shaw AGP, Vennell R (2000) Variability of water masses 
through the Mernoo Saddle, South Island, New Zealand. NZ J Mar Freshw Res 1:103-116

Suthers IM, Frank KT (1991) Comparative persistence of marine fish larvae from pelagic versus demersal eggs off southwestern Nova Scotia, Canada. Mar Biol 108: 175-184

Thresher RE (1984) Reproduction in reef fishes. TFH Publications, Neptune City, NJ

Tricklebank KA, Jacoby CA, Montgomery JC (1992) Compo-

Editorial responsibility: Otto Kinne (Editor),

Oldendorf/Luhe, Germany sition, distribution and abundance of neustonic ichthyoplankton off northeastern New Zealand. Estuar Coast Shelf Sci 34:263-275

Waters JM, Dijkstra LH, Wallis GP (2000) Biogeography of a southern hemisphere freshwater fish: how important is marine dispersal? Mol Ecol 9:1815-1821

Webb BF (1973) Fish populations of the Avon-Heathcote estuary 2: breeding and gonad maturity. NZ J Mar Freshw Res 7:45-66

Submitted: February 18, 2002; Accepted: October 22, 2002

Proofs received from author(s): April 8, 2003 